\title{
INTERNATIONAL INSTITUTIONS WITH AUTHORITY IN THE MATTER OF INSOLVENCY
}

\author{
Bogdan Radu \\ B. Radu \\ Faculty of Judicial and Administrative Sciences \\ "Dimitrie Cantemir" Christian University, Bucharest, Romania \\ *Correspondence: Bogdan Radu, "Dimitrie Cantemir" Christian University, 176 Splaiul \\ Unirii, 4 District, Bucharest, Romania \\ E-mail: radubogdangabriel@yahoo.com
}

\begin{abstract}
The article aims at presenting the international context of the ongoing phenomenon of acute imposibility of debt paying, with which the economic environment all around the world has been dealing with for the past 5 years, more precise the international organisations that cooperate or help with the development of insolvency laws (including crossborder insolvency laws) or principles that should govern an insolvency law for a convergence towards a more efficient and predictable insolvency procedure. The study isn't concerned with the international professional associations, nongovernmental international organisations, legal subjects of the national law under which they came to be. Lastly there will be presented topics of interest to be considered together with points of action.
\end{abstract}

Key words: insolvency, bankruptcy, international organisations, UN, UNCITRAL, model law, EU, Council Regulation (EC) No 1346/2000.

\section{Introduction}

Felix qui nihil debet (happy is the one who owes nothing) - Beside the fact that it seems to be a Latin truism, in the current economical state of society, the absence of debt remains a desideratum. It should not necessarily be the worst element in a debtor's patrimony. If it is controlled, it may become an impulse, a real fuel for a fruitful mechanism allowing to cover the needs and reach the socio-economical aspirations of each person. The danger emerges when the assets succumb to the level of debt in an uncontrolled, irresponsible and edgy way.

"Bankruptcy comes from the word fallere, which means to cheat. In roman law, bankruptcy embodied a procedure called venditio bonorum that manifested itself by cessating the activity of the trader, confiscating and selling it's goods. In the small italian cities, the bankrupt merchants were considered felons. In 1673 the insolvency proceedings are regulated by the Colbert Ordinance, and in 1807 they are included in the french Commercial Code". 1

The domino effect produced worldwide by the financial crises has started many insolvency and crossborder insolvency proceedings. This is not an ended phenomenon since the affected countries are still looking for legislative solutions for equilibrating the internal market.

With this occasion, the mechanisms available to the creditors for recovering the claims from other national jurisdictions in a term as short as possible, were submitted to real challenges and the positive aspect consists of a better understanding of the weak points, their disadvantages and the starting of the works for improving and completing them. A current

\footnotetext{
${ }^{1}$ Dumitru Mazilu, International Comerce Law. General considerations, 7-th edition, Lumina Lex Publishing house, Bucharest, 2008, p. 217; For other details, Ana Birchall, Insolvency proceedings. Judicial reorganisation and the liquidation proceeding, 3-rd edition, Universul Juridic Publishing house, Bucharest, 2010;
} 
example is the V Work Group of UNCTIRAL which, at the 43 session that had place in New York between April $15^{\text {th }}-19^{\text {th }}$, wanted to clear the interpretation and the application of some extremely important notions of the UNCITRAL Model Law regarding the crossborder insolvency concerning the center of main interest or the obligations of the persons able to make the managerial decisions, usualy the administrator, in the period of time close to bankruptcy.

In Romania, the impact of the economical crisis has led many times to the change of the insolvency law ${ }^{2}$ and the most important ones are about the quantum of the limit value of the claim (gradually increasing from 3,000 lei to 45,000 lei) and the non-payment term from the date of payment and then the insolvency is presumed (from 30 days to 90 days) and it culminated with a coding intercession ${ }^{3}$ of this matter, reuniting both the stipulations of the pre-insolvency stage (the ad-hoc mandate and the preventive agreement) and the one of proper insolvency. Thus, the need to reconceptualise and reinvent some guilt terms based on the adaption of the norms to the needs of the practice in matter.

In an age where the national and regional policies tend towards convergence in order to ease the intensification of the economical exchanges, when the logistics allows the intercontinental transport of the merchandise in much easier conditions, when the electronic means have a more and more important place in the accomplishment of the international commercial transactions, we should also look to the penumbra of this globalisation phenomenon, by observing, analysing, responding to certain dilemmas created by the ramifications of the negative effects of a status of incapacity of payment propagated beyond the limits of only one jurisdiction.

Based on the need to delimitate the organisms able to conceive some norms of broad applicability in the international context, providing thus a minimum treatment standard in the procedures, leading lines in the elaboration of the intern legislations, easing an efficient and predictable practice, one of the raised questions is - Which international organism is able to guide, to suggest a transnational organisation in matter of insolvency, considering the international law norms and the numerous and varied regional or international juridical systems?

Whereas every government is supposed to protect the national interest in the international context, Romania's accession to different intergovernmental organisms with concerns in draining the free exchange policies between its members, makes sense. In this purpose, we may also consider the participation to international organisations having a financial vocation (for example, the International Monetary Fund, the World Bank Group) by means of which we may obtain a support in solving the potential problems appeared in the context of disbalancing the payment balance.

Without minimising the importance of other international actors, certain international professional organisations have an impact in the matter of developing the insolvency principles, as they are co-opted in the elaboration of the different policies of crossborder insolvency, of the international coding or of the best collections of practices in the matter (e.g. INSOL International, International Bar Association).

Shortly, the most important international organisms involved in the international cooperation in the matter of insolvency are:

3. The United Nations Commission on International Trade Law (UNCTIRAL)

The Commission on International Trade Law (UNCITRAL) represents the basic structure in matter of the United Nations Organisations, focused on the gradually development and coding of the international law.

The necessity to support the international trade has an immeasurable importance, as it works on several plans, even reaching beyond the war policies (we noticed that there are

\footnotetext{
${ }^{2}$ Law 85/2006, published in the Official Gazette of Romania, Part I no. 359 from 21.4.2006;

${ }^{3}$ At this time the Insolvency Code is still in public debate;
} 
smaller chances to start aggression acts against a country with strong economical connections).

Under the universal vocation of U.N.O. (it is currently constituted of 192 members), it is normal for one of its legal bodies to be concerned with the modernisation and the harmonization of the international commercial rules for its members. The legitimacy of this approach resides even in the text of the U.N.O. Charter preamble stating, among others, that for reaching the purpose it is instituted for, it commits too contract international mechanisms for promoting the economical and social progress for everyone - since UNCITRAL is one of these mechanisms. The process has place by negotiating the instruments with a broad variety of participants, such as the member states of UNCITRAL, the non-member states, governmental and non-governmental institutions. The result consists of recognition and a broad assimilation of these texts, offering favourable solutions for all the countries, no matter the legal traditions or the economical development degree.

Based on the lack of another UNO organism familiar and devoted to the international trade, of the General Secretary's report on the progressive development of the international trade law ("Schmitthoff Study"), of the conviction according to which it is wanted for this organism to have an important role in the field, on December $17^{\text {th }}, 1966$ with the occasion of the $1497^{\text {th }}$ plenary meeting, the Resolution of the General Assembly 2205 (XI) was adopted and it actually settled UNCITRAL

The juridical texts of UNCITRAL (conventions, model laws, legislative guides) may be adopted by the states by the regulation in the domestic legislation.

The difference between model laws and conventions consists of the fact that the first one represents a pattern suggested to the legislative of a state as a model for the development of an intern law, while the convention is mandatory for the states or the entities that may be a part of it.

The UNCITRAL model law regarding the crossborder insolvency focuses on authorizing and encouraging the cooperation and coordination between the jurisdictions, not necessarily a uniformization of the substantial law. This, in its analysis, should be corroborated together with: a) its guides which may help the national authorities or the legislative bodies to evaluate different approach ways together with the valid solutions and to choose the most adequate one for the national context (the Legislative Guides of UNCITRAL on the Insolvency Law - parts one and two, 2004; part three, 2010); b) the texts elaborated by UNCITRAL for easing the judges' activity by offering uniform interpretations to the stipulations, increasing thus the predictability in the application of the model law; c) the practical cooperation guide in matter of crossborder insolvency, responding thus to the procedural and substantial difficulties created by the many judicial systems covered by such an insolvency.

By means of the principles stipulated in the preamble of the Model Law regarding the crossborder insolvency, it is followed a) a cooperation between the courts and other authorities or organisms of the states involved in crossborder insolvency procedures; b) to offer a degree of legal predictability for economical exchanges and other investments; c) a just and efficient procedure of crossborder insolvency protecting the rights of all the creditors or stakeholders (a stakeholder is an affected person or group which may influence or which has something to say referring the activities, the products or the services of a company), including the debtor's ones; d) to protect and maximise the debtor's fortune; e) to safeguard the enterprises having financial difficulties, protecting thus the investments and the employment.

Nationally, the international legislation was harmonized by adopting Law 637/2002 regarding the reports of international law in the insolvency field, thus Romania being one of the first countries which developed a legislation based on the UNCITRAL Model Law regarding the crossborder insolvency, next to Eritrea (1998), Japan (2000), Mexico (2000), South Africa (2000) and Montenegro (2002). 
A healthy policy regarding the insolvency law may be one of the pieces forming an efficient economical and financial system. The process in front of the courts wants to be a secondary means of solving the disputes where we may reach preferably only if the negotiations fail, seeing thus the importance of the extrajudicial mechanisms of insolvency relieving the judicial activity by reaching to a consensus between the parties "in the shadow" of the law, certainly conditioned by unequivocal stipulations providing a certain predictability in the final result op the opening of an insolvency procedure.

4. The European Parliament, the European Union Council as organs having an enactment power in the framework of the European Union.

The main organisms of the European Union having enactment attributions are the European Parliament and the European Union Council (the Council).

According to the Dictionary of European Comunity terms ${ }^{4}$, "The European Parliament is one of the main EC institution, established by the Treaty of the European Coal and Steel Community $^{5}$, in the form of a Parliamentary Assembly composed of member states' representatives (art. 20 of the ECSC treaty)"

Across the last decades, the power of the European Parliament has constantly increased; as a consequence, it currently exerts the co-legislator role in almost all the fields enacting the European Union, adopting or changing the suggestions of the European Commission, next to the Council.

According to art. 223 of the Treaty on the Functioning of the European Union, the European Parliament elaborates a project for establishing the necessary stipulations which could allow the election of its members by a direct universal vote according to a uniform procedure in all the member states or according to the common principles of all the member states. Therefore, we may notice that it is not about a European uniform law, but there may be specific stipulations as long as they are compliant to the common principles of all the member states.

The lists of candidates may be suggested only by the political parties, the political alliances and the citizen organisations belonging to the legally constituted national minorities, and also by the electoral alliances constituted in the conditions of Law no. 33/2007 regarding the elections organisation and development for the European Parliament, as further amended and completed.

The European Parliament is reunited in a yearly session the second Tuesday of March. The European Parliament may be reunited in an extraordinary session, at the request of most of the members who compose it, of the Council or of the Commission.

The legislative procedure specific to the European Union is translated by a mechanism where the two institutions adopt legislative documents either in the first reading, or in the second one. If the two institutions do not get to an agreement after the second reading, a conciliation committee is convoked, proceeding thus to the third reading.

The European legal framework in the matter of insolvency is represented by the Regulation (CE) 1346/2000 from May 29 ${ }^{\text {th }}$, 2000 regarding the insolvency procedures, published in the Official Journal no. L 160/2000 benefits from direct implementation, considering Romania's accession to the European Union on January $1^{\text {st }}$, 2007. From that moment, we step into a new age that was to stay under the reforms and the modernisation, all of them under the guardianship of one of the biggest, the most complex and particular international organisations of integration. This is different from other organisations by certain special features: it creates the new juridical order with direct implementation in the national juridical system; there are institutions where representatives of the member states participate, but they are independent from them.

\footnotetext{
${ }^{4}$ Ion Jiga, Andrei Popescu, Dictionary of European Community terms, Lumina Lex Publishing house, Bucharest, 2000, p. 136.

${ }^{5}$ Also known as the Paris Treaty of 1951; it expired in 2002.
} 
There are problems when recognizing a procedure stipulated in the Romanian legislation, but not in the European one, and vice versa - here, I mean the procedure of personal bankruptcy recognized by the Regulation but with no place in the intern legislation, and in the regulation sphere of the regulation, the lack of the reorganisation procedures in the pre-insolvency stage, recognized by the Law of the preventive concordat and ad-hoc mandate, Law no. 381/2009.

The Regulation (CE) 1346/2000 has appeared based on the intensification of the crossborder economical activities of the enterprises, on the desire to provide the good functioning of the intern market. Before the adoption of this regulation which uniforms the insolvency procedure at the community level, the parties were tempted to transfer the goods or the judicial procedures from a member state to another in order to obtain a more favourable juridical situation ("forum shopping").

The document is efficient because it is an imperative, community juridical document directly applicable to the member states, even if an update of its stipulations is good for regulating the disadvantages felt after the financial crisis that started in 2008.

5. Other international organisms offering cooperation frameworks in the matter are:

- The International Monetary Fund (IMF) - Orderly \& Effective Insolvency Procedures (1999). The fruit of an intensive intellectual effort made by the IMF legal department, "Disciplined and efficient procedures of Insolvency" does not want to be a standard coding with an imperative imposing to the member states, even if it sometimes expresses its preference for one of the solutions, but it is rather a report of insolvency political themes addressed by the states when they were in the elaboration stage of an insolvency law.

- The World Bank Group (WBG) - Principles for the system of an efficient insolvency and of the creditors' rights (2001, reviewed in 2005). Emerged based on the financial crisis crossed by the emerging markets at the end of the ' 90 s, at the pressure of the international community, WBG has elaborated the first barometer internationally accepted, measuring the efficiency of the creditors' domestic rights and the insolvency systems.

IMF and WBG are international organisations with a broad participation of the world states. The operational activity of IMF and WBG consists of conceiving reports and of observing the standards and codes. The use of the evaluations based on the Procedures and on the Principles was useful in the developing and operative work and in offering efficient assistance to the member states.

IMF works for supporting the global monetary cooperation, for providing the financial security, for facilitating the international trade, for promoting a high rate for occupying the manpower and a strong economical increase, and also for reducing global poverty.

WBG is formed of 5 institutions: the International Bank for Reconstruction and Development (IBRD), which granted loans to the countries with average and low incomes, but solvable ones; the International Development Association (IDA), which granted credits with no interest to the most poor countries; the International Financial Corporation (IFC) works exclusively in the private sector; the Multilateral Investments Guarantee Agency (MIGA), with attributions in promoting the foreign investments in the developing countries, offering political guarantees; the International Centre for Regulating the Controversies in the Investment Field (ICSID) facilitates the conciliation and the international arbitrage in disputes related to the investments.

Having 188 members each, IMF and WBG are among the biggest international organisation (ONU has currently 192 members). The membership to IBRD, according to art. 2 section 1 of the own regulation of organisation and functioning, depends on the membership to FMI, and for being a part of IDA, IFC and MIGA it is necessary to subsequently register to IBRD.

\section{Conclusions}


The slow but steady paced emergence out of the economical crisis in which the whole world has collapsed into in 2008 represents another ground for an imperative renewal of the way insolvency is regarded together with a legislative revival concerning bankruptcy. This tendency needs to be given satisfaction with the aid of the most important specialized international institutions, better able to direct the harmonisation of transnational legislations.

The European crossborder insolvency mechanism remains a faulty, poor and scanty one, having major issues on the level or recognition of procedures envisioned by the romanian legislation but not the EC regulation, and vice versa - I'm refering here to the personal (not corporate) bankruptcy proceedings, recognised by the EC regulation but not by the romanian Insolvency law, thus being at risk of undergoing an infringement procedure, and to the lack of concern on the European Union level regarding the preinsolvency proceedings, Romania having in effect such law.

Concerning UNCITRAL Model Law on Crossborder Insolvency, now it's the perfect moment to promote the benefits of this legal framework throughout its members, a step objectified in a wider implementation of a national insolvency regulation having in regard said model law. It would translate in a better, more efficient arming against future economical crises, this phenomena having been demonstrated its cyclical character.

\section{Bibliography}

Dumitru Mazilu, Dreptul comerțului internațional. Partea generală, VIIth edition, Lumina Lex Publishing House, Bucharest, 2008;

Ana Birchall, Procedura insolvenței. Reorganizarea judiciară şi procedura falimentului. Note de curs incluzând şi procedura concordatului preventiv şi a mandatului adhoc, III-rd edition, "Universul Juridic" Publishing House, Bucharest, 2010;

Dan Vătăman, Organizații europene şi euroatlantice, "C.H. Beck", Bucharest, 2009;

Andrei Popescu, Ion Diaconu, Organizații europene şi euroatlantice, "Universul Juridic" Publishing House, Bucharest, 2009;

Ion Jiga, Andrei Popescu, Dicționar de termeni comunitari, "Lumina Lex" Publishing House, Bucharest, 2000;

www.uncitral.org

www.worldbank.org

www.imf.org

http://www.europarl.europa.eu

http://www.consilium.europa.eu 